\title{
AN EVALUATION OF MERCURY REMOVAL IN THE IDMS USING THE NITRIC ACID FLOWSHEET (U)
}

WSRC-TR--92-492

by N. D. Hutson

DE93 006883

Westinghouse Savannah River Company

Savannah River Site

Aiken, South Carolina 29808

Other Authors:

\section{DISCLAIMER}

\begin{abstract}
This report was prepared as an account of work sponsored by an agency of the United States Government. Neither the United States Government nor any agency thereof, nor any of their employees, makes any warranty, express or implied, or assumes any legal liability or responsibility for the accuracy, completeness, or usefulness of any information, apparatus, product, or process disclosed, or represents that its use would not infringe privately owned rights. Reference herein to any specific commercial product, process, or service by trade name, trademark, manufacturer, or otherwise does not necessarily constitute or imply its endorsement, recommendation, or favoring by the United States Government or any agency thereof. The views and opinions of authors expressed herein do not necessarily state or reflect those of the United States Government or any agency thereof.
\end{abstract}

This paper was prepared in connection with work done under Contract No. DE-AC09-89SR18035 with the U. S. Department of Energy. By acceptance of this paper, the publisher and/or recipient acknowledges the U. S. Government's right to retain a nonexclusive, royalty-iree license in and to any copyright covering this paper, along with the right to reproduce and to authorize others to reproduce all or part of the copyrighted paper. 


\section{DISCLAIMER}

This report was prepared as an account of work sponsored by an agency of the United States Government. Neither the United States Government nor any agency thereof, nor any of their employees, makes any warranty, express or implied, or assumes any legal liability or responsibility for the accuracy, completeness, or usefulness of any information, apparatus, product, or process disclosed, or represents that its use would not infringe privately owned rights. Reference herein to any specific commercial product, process, or service by trade name, trademark, manufacturer, or otherwise does not necessarily constitute or imply its endorsement, recommendation, or favoring by the United States Government or any agency thereof. The views and opinions of authors expressed herein do not necessarily state or reflect those of the United States Government or any agency thereof.

This report has been reproduced directly from the best available copy.

Available to DOE and DOE contractors from the Office of Scientific and Technical Information, P. O. Box 62, Oak Ridge, TN 37831; prices available from (615) $576-8401$.

Available to the public from the National Technical Information Service, U. S. Department of Commerce, 5285 Port Royal Rd., Springfield, VA 22161. 


\author{
Keywords: DWPF, IDMS, Mercury, \\ Nitric Acid Flowsheet, \\ Late Wash \\ Retention: Permanent \\ CC: L. M. Papouchado, 773-A \\ L. F. Landon, 704-T \\ C. T. Randal1, 704-T \\ J. T. Carter, 704-1T \\ M. J. Plodinec, 773-A \\ J. R. Zamecnik, 704-1T \\ J. A. Ritter, 704-1T \\ C. W. Hsu, 704-1T \\ R. E. Eibling, 704-T \\ SRTC Records (4)
}

October 22,1992

TO: E. W. Holtzscheiter, 773-A

FROM: N. D. Hutson, 704-1T

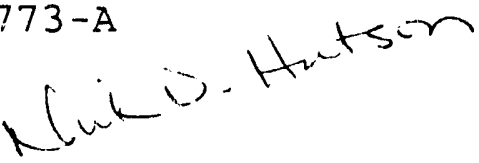

\title{
An Evaluation of Mercury Removal in the IDMS Osing the Nitric Acid Flowsheet ( 0 )
}

\section{Introduction and summary}

The present DWPF flowsheet calls for the chemical treatment of waste sludge with 90 wto formic acid prior to the addition of the Precipitate Hydrolysis Aqueous (PHA) product. An alternative processing methodology, denoted the "Nitric Acid Flowsheet", has been proposed. In the application of this flowsheet, nitric acid would be used to neutralize sludge base components (hydroxides and carbonates) prior to the addition of late wash PHA. The late wash PHA will contain sufficient quantities of formic acid to adequately complete necessary reduction-oxidation (REDOX) reactions.

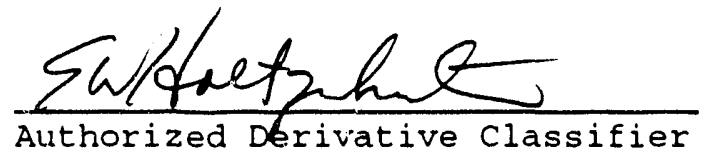


Most important of the REDOX reactions is the reduction of mercury to the element" 1 state. Reducing the mercury to the metallic state allows - to be steam stripped and removed during normal sludge processing. Mercury reduction, stripping, and removal via the formic acid flowsheet have been demonstrated successfully on several scales.1,2,3,4 In order for the Nitric Acid Flowsheet to be a viable alternative, it must be shown that mercury can be adequately reduced, steam stripped, and removed from the waste sludge. Four runs have been completed in the pilot-scale Integrated DWPF Melter System (IDMS) which were conducted in order to demonstrate the viability of this alternate flowsheet.

Based on the results, it appears that the design basis mercury endpoint $(0.45 \% \mathrm{Hg})$ can be attained without increasing the SRAT cycle time. Steam stripping efficiencies were good (exceeding the $33 \%$ design basis) for runs which used PHA with the reference Late Wash acid content 10.26 $0.30 \mathrm{M})$.

\section{Background}

Mercury is the most hazardous non-radioactive component in Savannah River Site (SRS) High Level Waste. The mercury has been used in the SRS separations processes as a catalyst in the nitric acid dissolution of spend fuel rods. Since mercury and mercury compounds decompose at temperatures much less than $1150^{\circ} \mathrm{C}$, any mercury present at vitrification will exit with he melter offgas. This mercury could be present in the melcer offgas stream as a complex mixture of halides, oxides, and metal. This mixture would be very difficult to process, recover, and purify from the melter offgas stream. Further, mercury halides are very corrosive, especially at elevated temperatures. Therefore, the Defense waste Processing Facility (DWPF) has planned to remove most of the mercury prior to vitrification via reduction to the elemental state with formic acid and removal via steam stripping in the Sludge Receipt and Adjustment Tank (SRAT). The elemental mercury is then collected and washed in the Mercury water Wash Tank, purified in the Mercury Purification Cell, and removed from the system.

In 1982, Janes ${ }^{3}$ conducted experiments in the $1 / 200^{\text {th }}$ scale SRAT in order to define a design basis for mercury removal in the DWPF. The results indicated that a steam stripping efficiency of $33 \%$ (approximately $3 x$ the theoretical. amount of steam based on vapor pressures) could be assumed for sludges with mercury concentrations above 0.8 wt $\%$ as shown in Figure 1. Janes also indicated that the steam requirement is doubled (to $6 \mathrm{x}$ theoretical) at mercury concentrations of 0.45 wt $\%$. This value (0.45 wt $\%$ ) was, therefore, chosen as a logical endpoint. The average mercury removal was predicted to be $75+8$. 


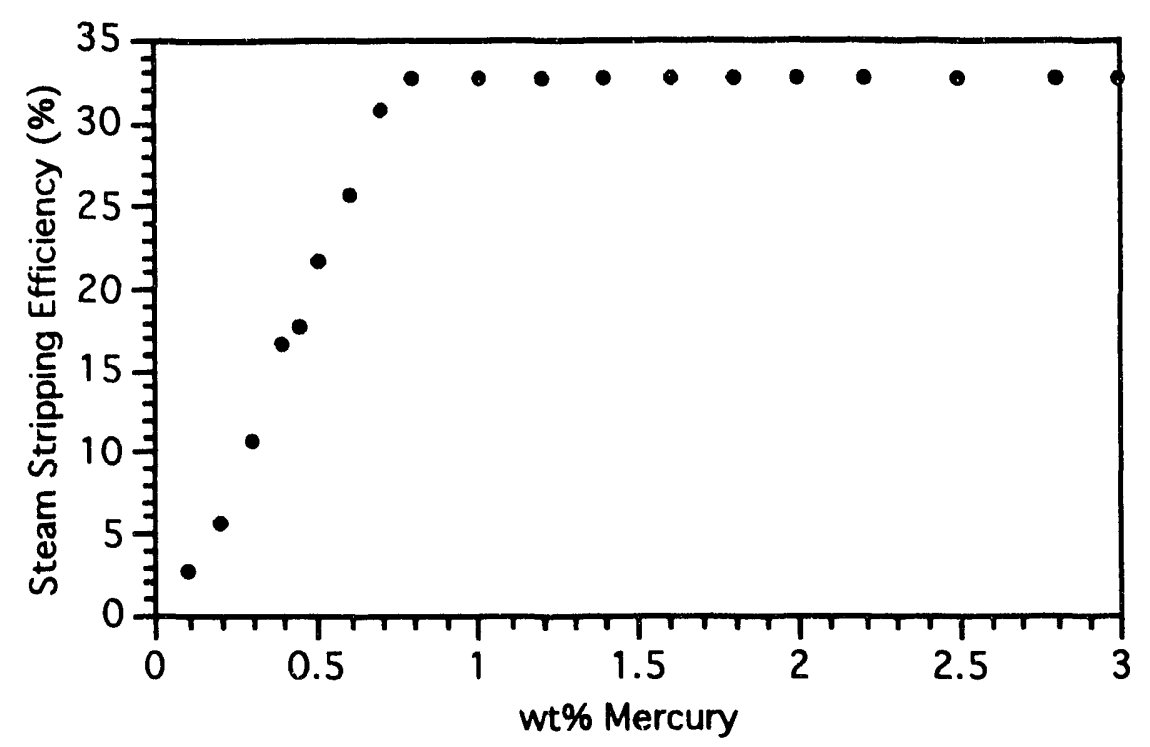

\section{Figure 1. Small scale Mercury stripping Efficiency ${ }^{3}$}

In 1991, Hutson, et.al.4 reported the results of experiments performed in the pilot-scale Integrated DWPF Melter system (IDMS) using the formic acid flowsheet. The results of the three-run campaign indicated that more than $50 \%$ of the initial mercury was removed during the formic acid addition/reflux period. During this reflux period (approximately 6 hours), steam stripping efficiencies were 70 - 85\%, far exceeding the DWPF design basis of 33\%. In contrast, during the PHA addition/concentration periods, the mercury steam stripping efficiencies were very low (2 - 11\%). However, this is due to the fact that most of the mercury that will be stripped has already been stripped in the formic acid reflux period. Any additional mercury which is stripped in the PHA cycle $(25$ - 45\%) is stripped very early in the PHA cycle. The endpoint concentrations for the three runs ranged from 0.08 - 0.24 wt $\%$, again far exceeding the DWPF design basis. (Note that these IDMS runs had a starting mercury concentration of $1.2 \%$ versus the design basis of $3.0 \%$ ). Based on the results of these runs, it was concluded that additional reflux after completion of the PHA additionconcentration would not be necessary to adequately remove the mercury. Overall, more than $80 \%$ of the initial mercury was removed from the waste simulant in each of the three runs. 


\section{IDMS Nitric Acid Flowsheet Runs}

To date, four runs have been made in the IDMS facility using the proposed Nitric Acid Flowsheet. These runs used two types of SRS waste sludge simulations (HM and PUREX) and two types of PHA material (HAN-process PHA and Late Wash PHA). In each case, initia] mercury concentrations were targeted at 3.2 wt 8 which is the highest expected to be processed in the DWPF. All of the runs contained "HM levels" of noble metals (Ru, Rh, Pd, and Ag) and the potential alloying agents, Se and Te. The results of each run are discussed in greater detail in the following sections.

\section{IDMS HM4}

The first IDMS run which utilized the Nitric Acid Flowsheet was one which used an HM-type sludge simulant $\left(\approx 0.3 \mathrm{M} \mathrm{NO}_{2}^{-}\right.$) and HAN-process PHA $(0.08 \mathrm{M}$ acid). This run is referred to as "HM4" and was conducted in late February 1992. Approximately 72 gallons of $7.5 \mathrm{M}$ nitric acid were added to 1100 gallons of sludge. After the addition was completed, the material was refluxed for 3 hours before the addition of approximately 2100 gallons of the HAN-process PHA. The PHA material was added in 150 -gallon batches.

Figure 2 shows the amount of mercury in the IDMS SRAT/SME during the course of the HM4 operation. One can see that, aside from the analytical scatter, the mercury stays constant until the start of the PHA addition at which time it starts to decline sharply. The mercury content continues to decline until approximately $75 \%$ has been removed. No steam stripping is evident during the SME cycle as the mercury content actually appears to increase during this phase of operation. The mercury concentration after completion of the SRAT processing was 0.59 wt\%.

The steam stripping efficiency during the HM4 operation is shown in Figure 3. As can be seen in the graph, the efficiency starts at $0 \%$ and increases sharply at the beginning of the PHA addition. The efficiency peaks at about $40 \%$ and declines to 25-30\%, below the design basis of $33 \%$. 


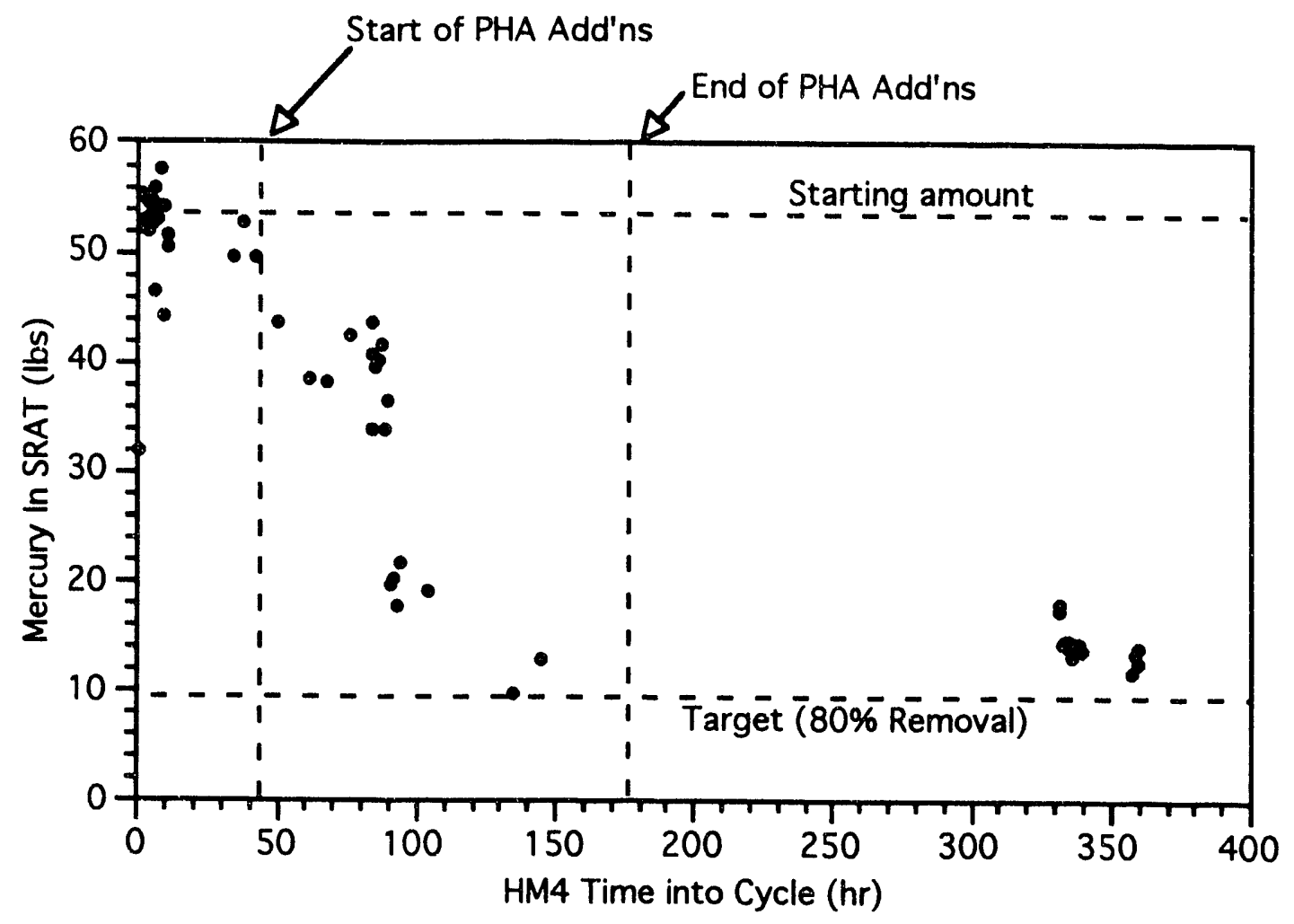

Figure 2. SRAT Mercury Content During IDMS mM4

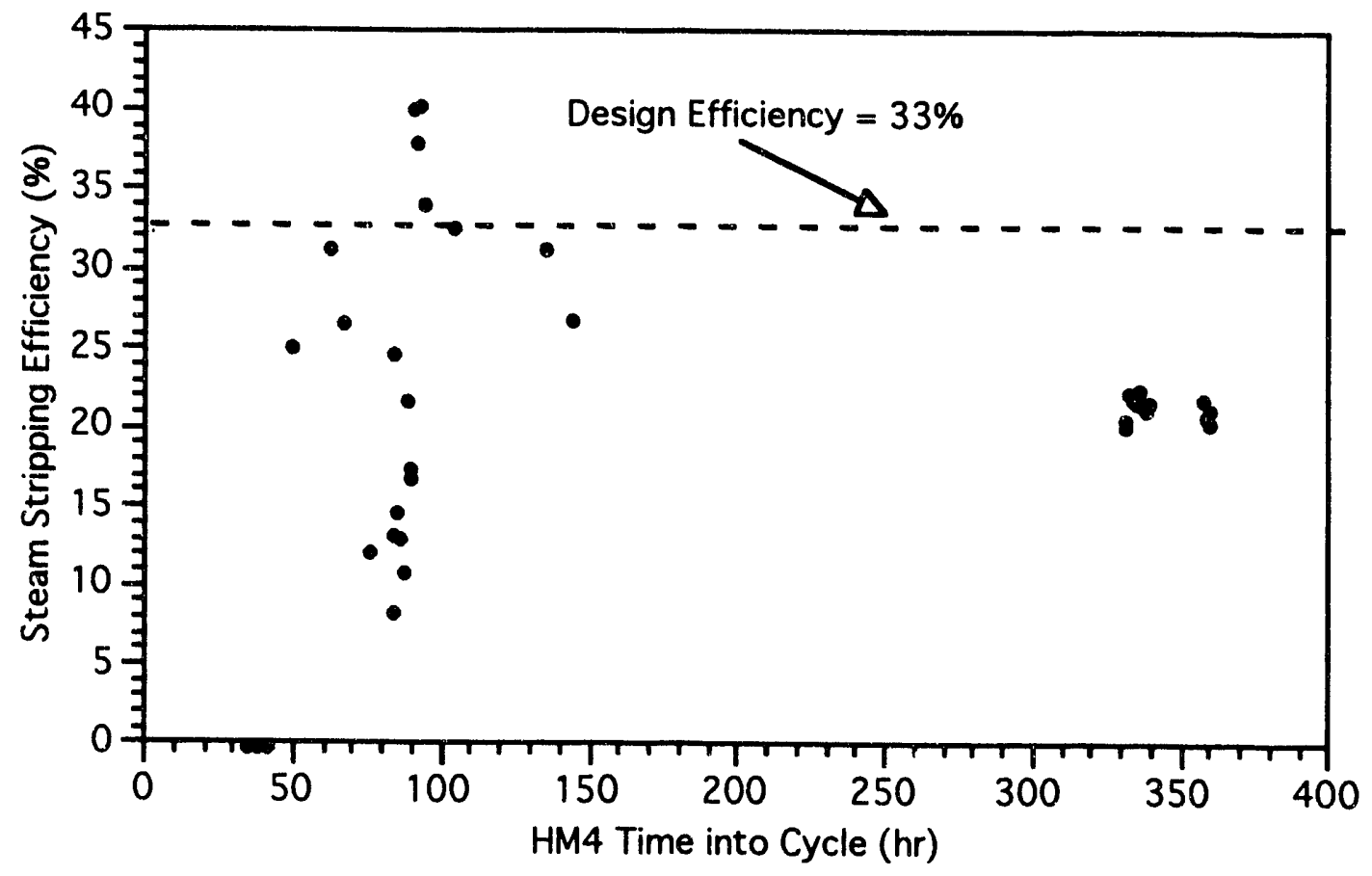

Figure 3. Steam stripping Efficiency During IDMS fM4 


\section{IDMS PX3}

The second IDMS run which utilized the Nitric Acid Flowsheet was one which used a PUREX-type sludge simulant $\left(0.0 \mathrm{M} \mathrm{NO}_{2}^{-}\right)$ and HAN-process PHA (spiked with formic acid to $0.3 \mathrm{M}$ acid). This run is referred to as "PX3" and vas conducted in mid May 1992. Approximately 35 gallons of 7.5 M nitric acid were added to 1100 gallons of sludge. After the addition was completed, the addition of the PHA material was initiated (no reflux period). The PHA material was added to the IDMS SRAT in 150-galion batches for an approximate total of 2100 gallons.

Figure 4 shows the amount of mercury in the IDMS SRAT/SME during the course of the PX3 operation. This plot shows a nice decrease in the mercury content throughout the PHA addition/concentration cycle. At the end of the SRAT processing, approximately $82 \%$ had been removed and the mercury concentration was 0.54 wto. As can be seen in Figure 4, additional steam stripping takes place in the SME cycle.

The steam stripping efficiency during the PX3 operation is shown in Figure 5. The plot is somewhat similar to that of HM4 (Figure 3). The efficiency begins at 0\%, sharply increases with the addition of PHA, and later declines. However, the efficiency for PX3 is considerably better than that of HM4. The peak efficiency is greater than 85\% and only at the end of SME operation does the efficiency decline to the design point of $33 \%$. 


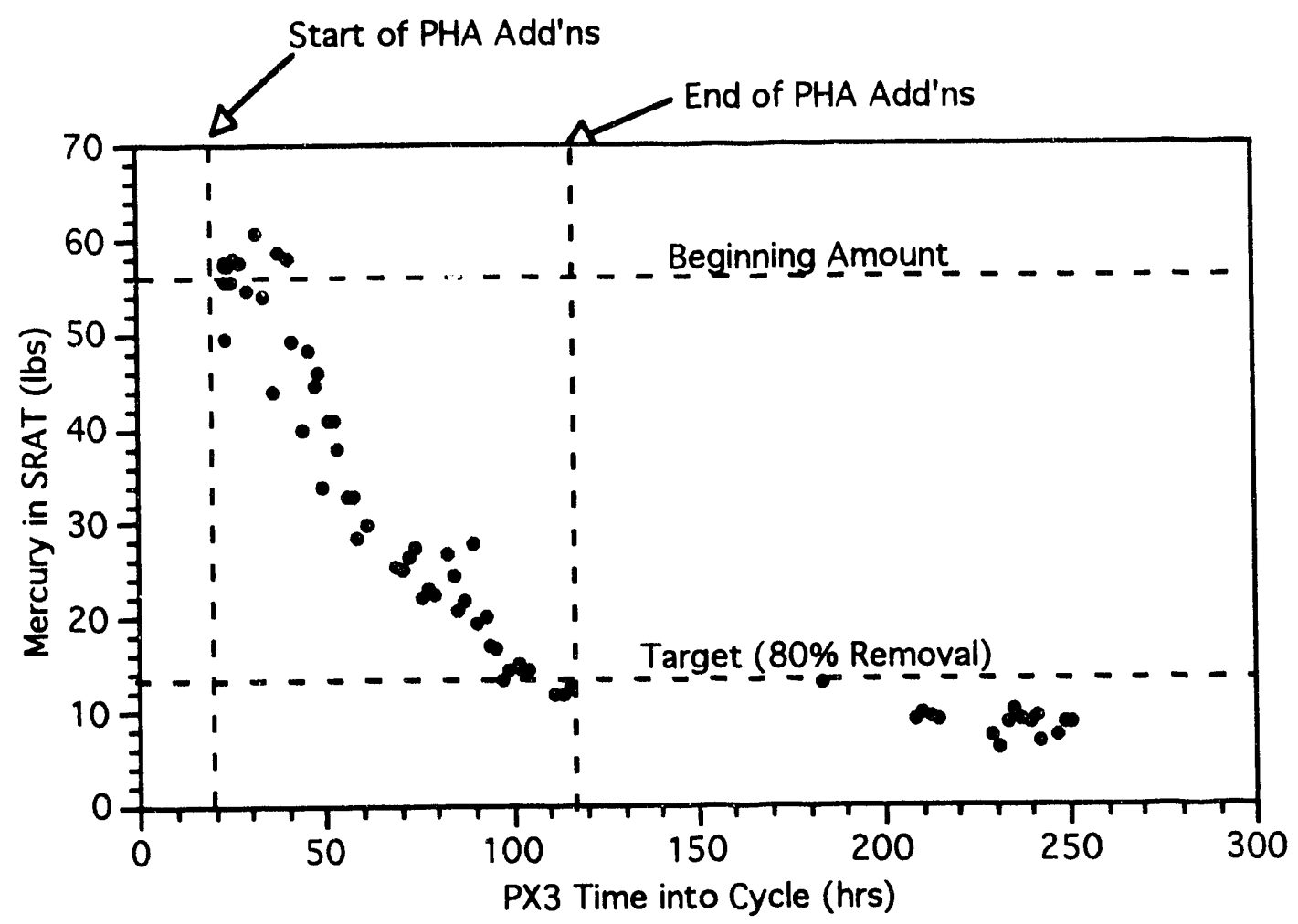

Figure 4. SRAT Mercury Content During IDMS PX3

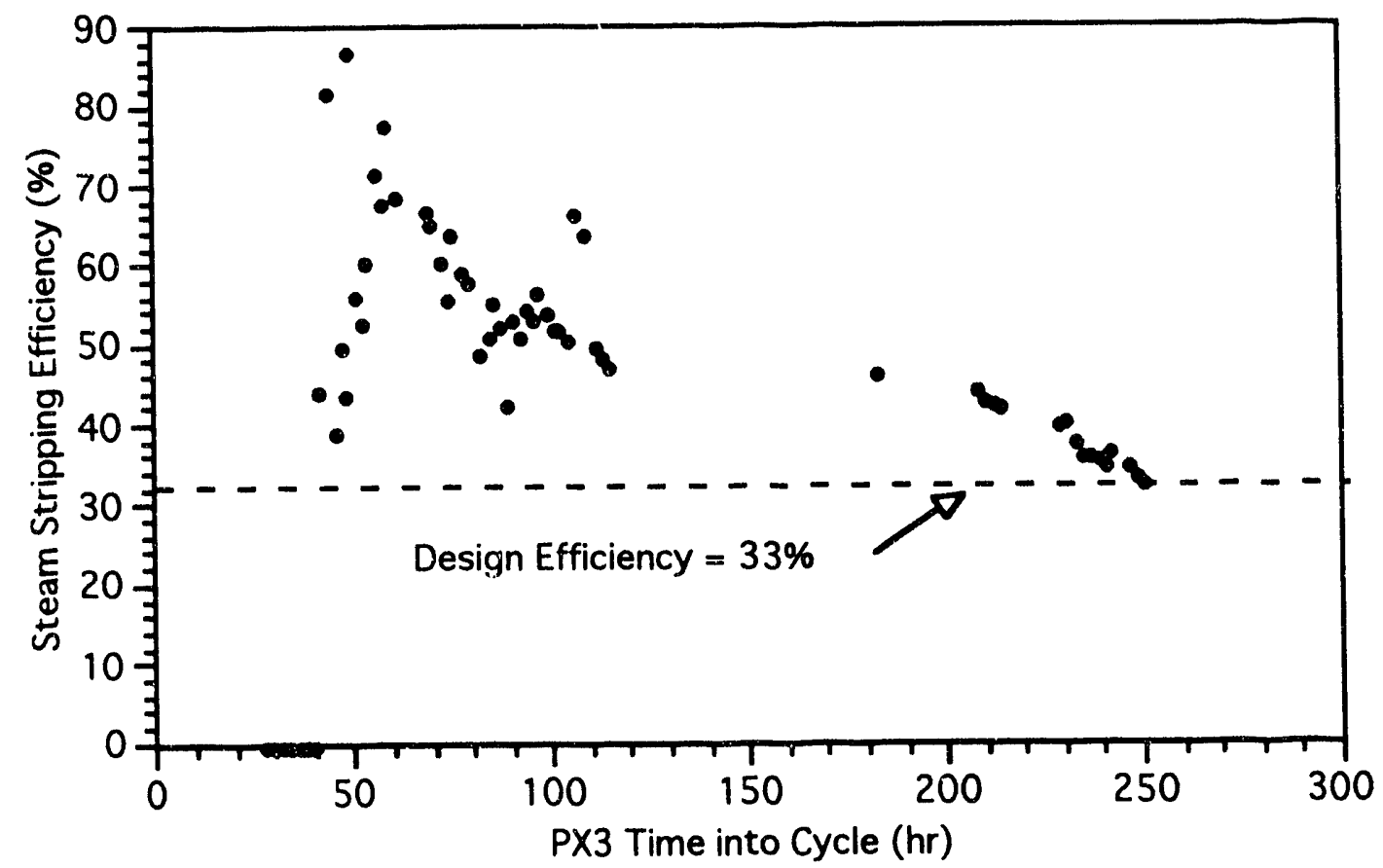

Figure 5. Steam Stripping Efficiency During IDMS PX3 


\section{IDMS PXA}

The third IDMS run which utilized the Nitric Acid Flowsheet was one which used a PUREX-type sludge simulant $\left(\approx 0.06 \mathrm{M} \mathrm{NO}_{2}{ }^{-}\right)$ and Late wash PHA $(0.26 \mathrm{M}$ acid). This run is referred to as "PX4" and was conducted in early July 1992. Approximately 35 gallons of $7.5 \mathrm{M}$ nitric acid were added to 1100 gallons of sludge. After the acid addition was completed, the addition of the PHA material was initiated (no reflux period). The PHA material was added to the IDMS SRAT in 150-200 gallon batches for an approximate total of 2100 gallons.

Figure 6 shows the amount of mercury in the IDMS SRAT/SME during the course of the PX4 operation. As with the corresponding plot for $\mathrm{PX} 3$, this plot shows a decline in the mercury content throughout the PHA addition/concentration cycle until the very end of the cycle when there seems to be an increase in the mercury content. At the end of the SRAT processing, 70 - $80 \%$ of the original mercury had been removed and the mercury concentration was 0.49 wt: As with PX3, additional steam stripping takes place in the PX4 S'AE cycle.

The steam stripping efficiency during the PX4 operation is shown in Figure 7. This plot is very similar (in the general trend, at least) with those of HM4 and $F X 3$. The efficiency increased sharply in the early stages of PHA cycle iaddition and concentration) and then declined to approximately $33 \%$ (the design efficiency) at the end of SRAT processing and through the early part of the SME cycle. 


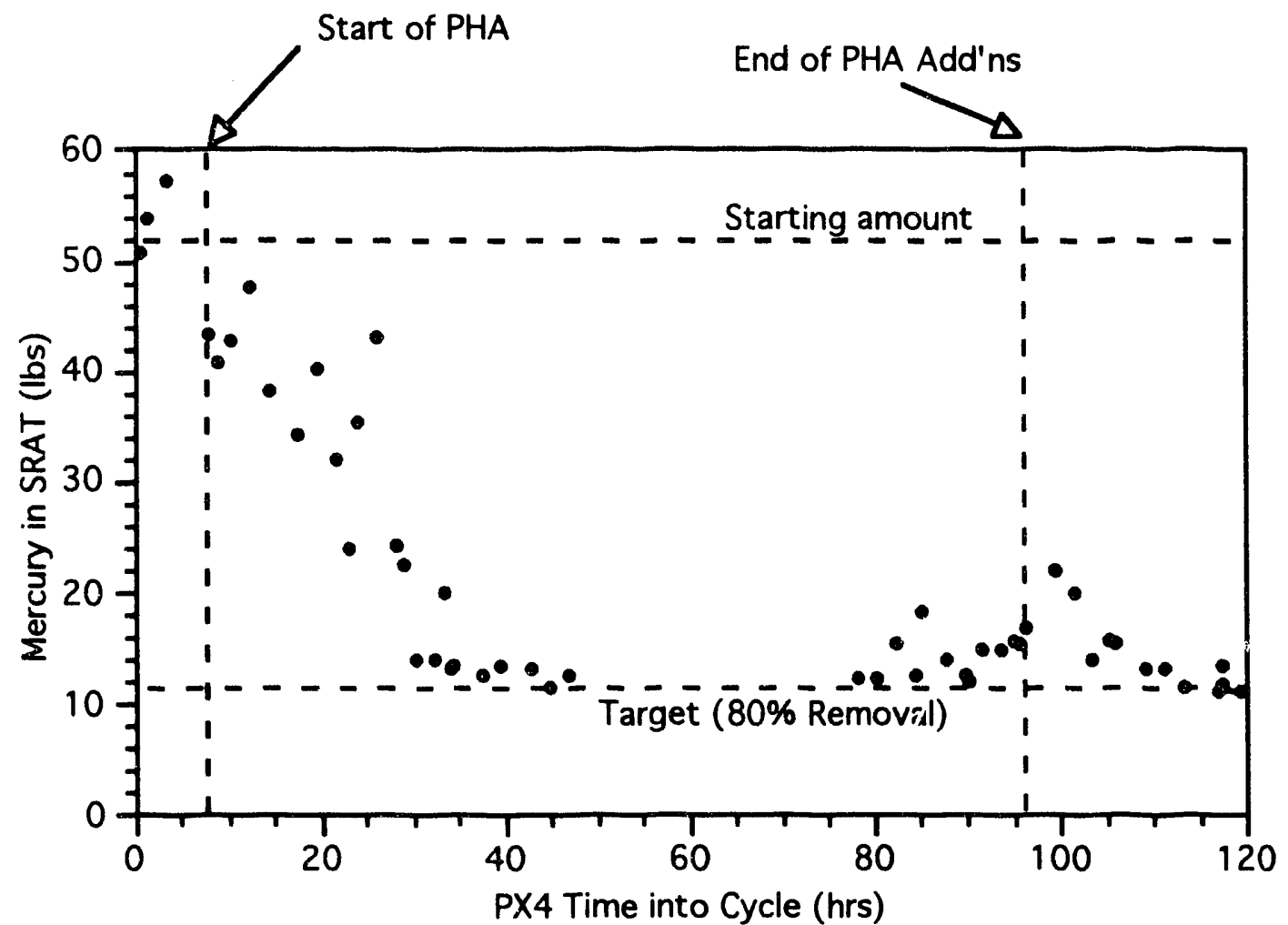

Figure 6. SRAT Mercury Content During IDMS PX4

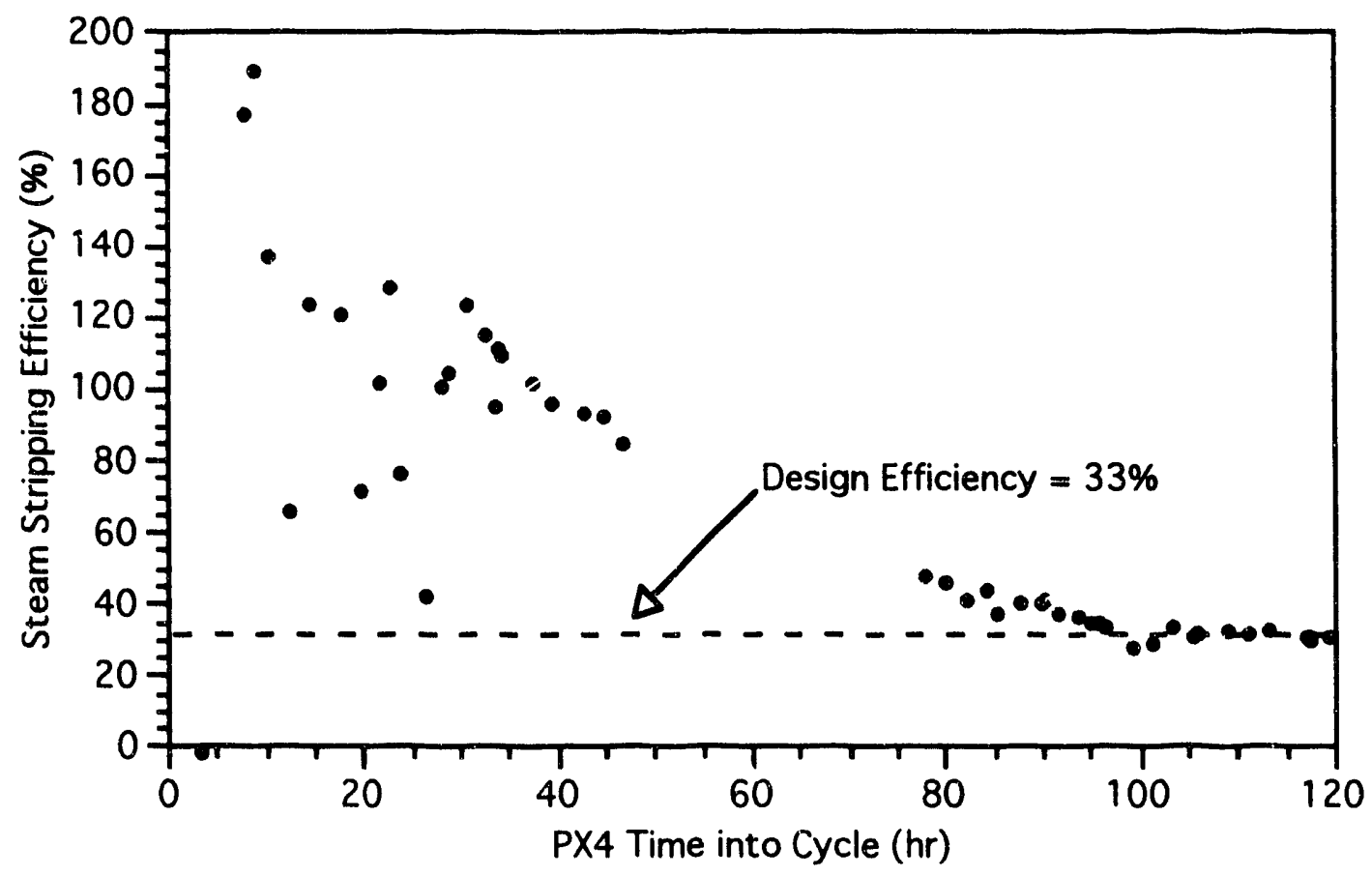

Figure 7. Steam stripping Efficiency During IDMS PX4 


\section{IDMS PX5}

The fourth IDMS run which utilized the Nitric Acid Flowshet was one which used a PUREX-type sludge simulant $\left(\approx 0.06 \mathrm{M}_{\mathrm{NO}} 2_{2}^{-}\right.$) and Late Wash PHA $(0.3 \mathrm{M}$ acid). This run is designated as "PX5" and was conducted in mid october 1992. Approximately 38 gallons of $7.5 \mathrm{M}$ nitric acid were added to 1100 gallons of sludge. After the acid addition was completed, the addition of the PHA material was initiated (no reflux period). The PHA material was added continuously to the IDMS SRAT at approximately $1.5-2.0 \mathrm{gpm}$. The material was evaporated by using 800 - $1000 \mathrm{pph}$ steam (@ $125 \mathrm{psi}$ ).

The data necessary to characterize the steam stripping efficiency and plot the mercury concentration with time is not available at the time of this report. (This information will be included in a general four-run summary report.) However, analysis of the SRAT product has been completed. The endpoint concentration for the PX5 SRAT was 0.03 wto $\mathrm{Hg}$. This corresponds to greater than $90 \%$ removal and far exceeds the 0.45 t target endpoint concentration.

This increased removal is most likely the result of maintaining a vigorous boil with high steam flows during the PHA addition. 


\section{Conclusions}

Table 1 shows a general summary of the pertinent data and from each of the three runs. From this, information and from analysis of the mercury content aid steam stripping efficiency plots, the followinc conclusions can be made:

- The steam stripping efficicency for IDMS HM4 was not good. However, $=75 \%$ of the original mercury was removed by the end of the SRAT cycle. The decreased efficiency may be due to the low acid content of the HAN-process PHA. Adequate mercury removal is probably a result of a longer SRAT CYcle time.

- In cases where the acid content was at nominal Late Wash levels $(\approx 0.26-0.35 \mathrm{M})$ the efficiency was good (consistently exceedir.g the 338 design basis).

- In all cases at least $75 \%$ of the original mercury present in waste sludge simulant was removed at the end of the SRAT iycle.

- Preliminary data from PX5 indicated that the SRAT Cycle endpoint mercury concentration was 0.03 wt $\%$, far below the design basis. This is most likely the result of an increased steam flow, an increased flux, and continuous addition of the PHA.

- Based on the results of PX5, it appears that the design basis mercury endpoint $(0.45 \% \mathrm{Hg})$ can be attained without increasing the SRAT cycle time.

Table 1. Pertinent Conditions For Each of the IDMs Nitric Acid Flowsheet Runs

\begin{tabular}{|c|c|c|c|c|c|c|c|c|}
\hline RUN ID & $\begin{array}{l}\text { Sludge } \\
\text { Amount } \\
\text { (Gal) }\end{array}$ & $\begin{array}{l}\text { Sludge } \\
\text { NO2(-) } \\
\text { (Molar) }\end{array}$ & $\begin{array}{c}7.5 \mathrm{M} \text { HNO3 } \\
\text { Amount } \\
\text { (Gal) }\end{array}$ & $\begin{array}{c}\text { PHA } \\
\text { Amount } \\
\text { (Gal) }\end{array}$ & $\begin{array}{c}\text { PHA } \\
\text { No3(-) } \\
\text { (Molar) }\end{array}$ & $\begin{array}{c}\text { PHA } \\
\text { HCOO(-) } \\
\text { (Molar) }\end{array}$ & $\begin{array}{c}\text { PHA } \\
\text { Acid } \\
\text { (Molar) }\end{array}$ & $\begin{array}{l}\text { Hg } \\
\text { End Conc } \\
(w t \%)\end{array}$ \\
\hline HM4 & 1100 & 0.29 & 72 & 2100 & 0.36 & 0.26 & 0.08 & 0.59 \\
\hline PX3 & 1100 & 0.00 & 35 & 2100 & 0.25 & 0.36 & 0.30 & 0.54 \\
\hline PX4 & 1100 & 0.07 & 35 & 2100 & 0.09 & 0.61 & 0.26 & 0.49 \\
\hline$P \times 5$ & 1100 & 0.07 & 38 & 2100 & 0.10 & 0.54 & 0.30 & 0.03 \\
\hline
\end{tabular}




\section{References}

1. R. E. Eibling, "Results of Mercury keduction with Formic Acid", USDOE Report DPST-83-1047, Savannah River Laboratory, Aiken, SC 29808 (1983).

2. R. E. Eibling, and J. R. Fowler, "Mercury Reduction and Removal During High-Level Radioactive Waste Processing and Vitrification", Published at the Materials Research Society Internal Symposium on the Scientific Basis for Nuclear Waste Management, Boston, MA, Nov 16-19, 1981, (USDOE Report DP-MS-81-49).

3. D. A. Janes, "DWPF Mercury Recovery Design Basis", USDO Report DPST-82-0893, Savannah River Laboratory, Aiken, SC 29808 (1982).

4. N. D. Hutson, et. al., "Integrated DWPF Melter System Campaign Report: Mercury Operation", USDOE Report WSRCTR-91-0363, Savannah River Laboratory, Aiken, SC 298 (1991). 

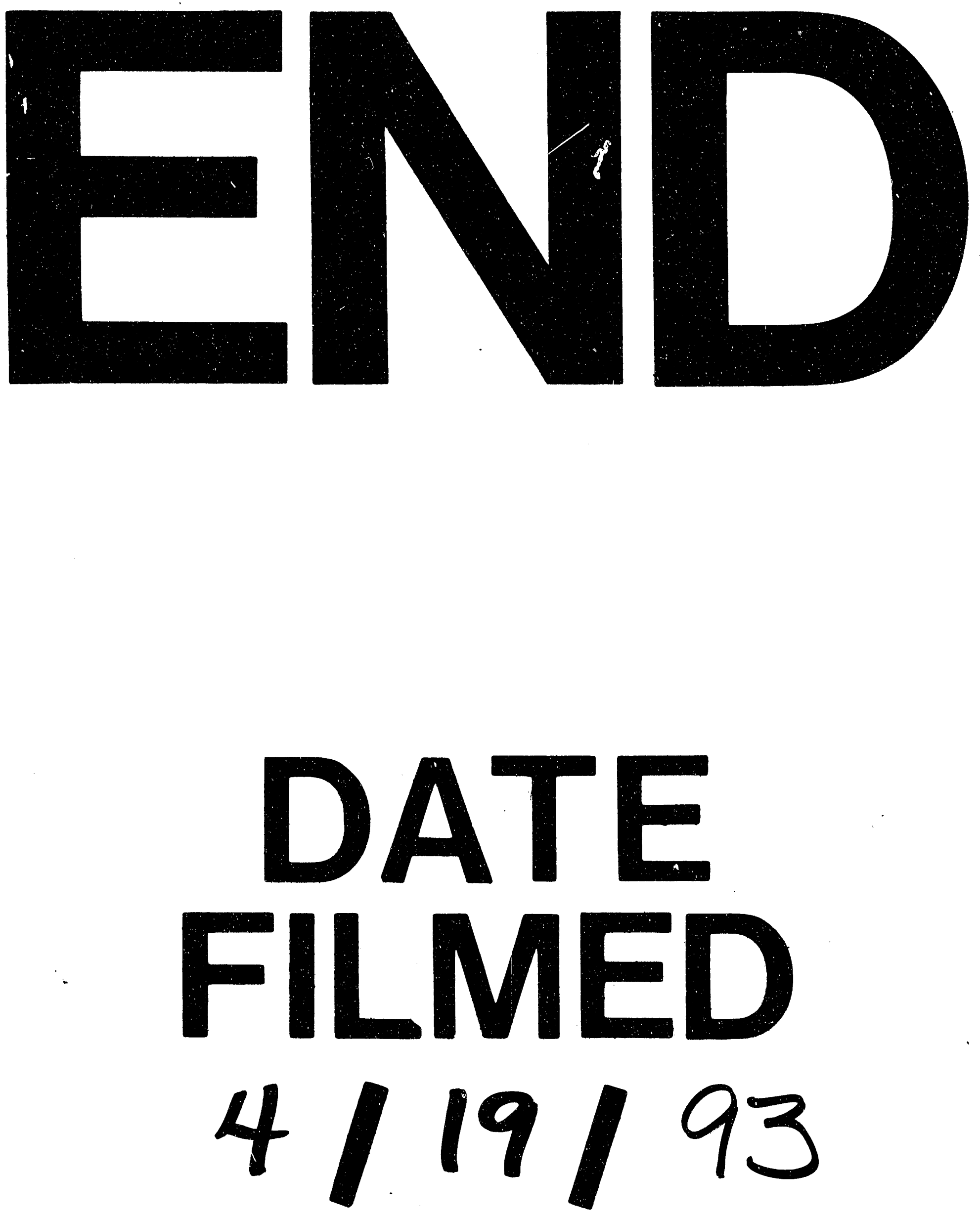
